ISSN: 1858-4837; E-ISSN: 2598-019X

Volume 16, Nomor 2 (2021),

https://jurnal.uns.ac.id/region

DOI: 10.20961/region.v16i2.37913

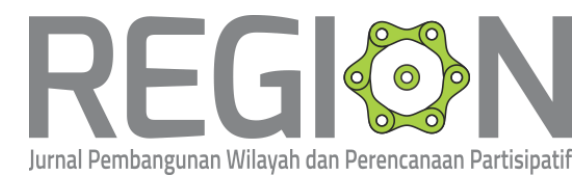

\title{
Prinsip-prinsip taman ramah anak berdasarkan sudut pandang pengguna
}

\section{Child-friendly park principles according to user's opinion}

\author{
C R Maria ${ }^{1}$, E E Pandelaki ${ }^{1}$, dan A Suprapti ${ }^{1}$ \\ ${ }^{1}$ Master of Architecture Department, Diponegoro University, Semarang, Indonesia
}

Corresponding author's email: catalinarosari@gmail.com

\begin{abstract}
Abstrak. Penyediaan taman yang ramah anak sebagai sarana anak beraktivitas dan berinteraksi dengan lingkungan merupakan salah satu indikator keberhasilan Kota Layak Anak (KLA). Penelitian ini dilakukan di Taman Citra Satwa yang merupakan salah satu taman terluas di Kota Semarang dengan berbagai fasilitas permainan dan olahraga. Sebagai taman yang baru beroperasi, taman ini telah banyak diminati oleh anak dan remaja dan memiliki potensi untuk dimaksimalkan sebagai taman ramah anak. Beberapa tahun terakhir, penelitian mengenai taman ramah anak membahas apa saja prinsip dalam taman ramah anak dan evaluasi penerapan prinsip tersebut pada beberapa taman di Indonesia. Namun belum ada penelitian tentang pendapat pengguna taman terhadap prinsip-prinsip tersebut. Penelitian ini bertujuan untuk menemukan pendapat pengguna terhadap prinsip yang dianggap paling mutlak dan prinsip mana yang masih dapat dikompromikan dalam taman ramah anak. Demi mencapai tujuan tersebut, penelitian ini menggunakan metode kualitatif rasionalisitik dalam menggali dan menganalisa pendapat pengguna terhadap prinsip-prinsip taman ramah anak yang sebelumnya telah dirumuskan berdasarkan teori dan temuan dari penelitian sebelumnya. Hasil temuan penelitian ini menunjukkan bahwa menurut pengguna taman, prinsip yang terpenting adalah kesehatan. Prinsip yang dianggap penting selanjutnya adalah prinsip daya tarik taman, keamanan dan keselamatan, kenyamanan, kebutuhan sosial, pembelajaran dan terkahir adalah prinsip kemudahan akses pada taman.
\end{abstract}

Kata Kunci: Pendapat Pengguna; Ramah Anak; Taman Ramah Anak

Received: December 12, 2019; Accepted: January 30, 2020; Available online: July 15, 2021

Copyright $\odot$ 2021, REGION: Jurnal Pembangunan Wilayah dan Perencanaan Partisipatif 


\begin{abstract}
The provision of child-friendly parks as a means for children to do activities and interact with the environment is one of the indicators of the success of a Child Friendly City (KLA). This research was conducted at Taman Citra Satwa, one of the largest parks in Semarang, which has various game and sport facilities. As a new park, this park has been attracting many children and youth. The park has a potential to be maximized as a Child-friendly park. In recent years, the research of child-friendly park only describes some principles and evaluates the application of those principle in several parks in Indonesia. There is no research about how park users think about these principles. This study aims to find the user's opinion about the most prioritized principle in the application of the concept of child-friendly parks. In order to achieve this aim, this study used a rationalistic-qualitative method to explore and analyze users' opinion towards the principles that have been formulated based on theories and previous studies. The finding of this study indicates that according to users, the most important principle is health. The principles that are considered important next are the attractiveness of the park, security and safety, comfort, social needs, education, and the last principle is the accessibility of the park.
\end{abstract}

Keywords: Child-Friendly; Child-Friendly Park; Users' Opinion

\title{
1. Pendahuluan
}

Konsep ramah anak saat ini menjadi pertimbangan penting dalam pembangunan baik di negara berkembang maupun negara industri. Konsep ramah anak pertama kali diawali oleh penelitian Kevin Lynch pada tahun 1971-1975 mengenai persepsi anak terhadap ruang kota. Penelitian tersebut kemudian dikembangkan oleh UNICEF pada tahun 1996 ketika menginisiasi gerakan Child Friendly City (CFC) pada United Nation Conference on Human Settlements yang kedua (Habitat II), yang mengemukakan bahwa kesejahteraan anak merupakan indikator utama dari sebuah masyarakat dan pemerintahan yang sehat. Program CFC menghimbau negara untuk mendukung adanya program pembangunan terpadu yang berbasis hak anak [1]. Di Indonesia, program ramah anak diterapkan melalui program Kabupaten/Kota Layak Anak (KLA). KLA adalah program pembangunan yang berbasis hak anak. Kebijakan ini sejalan dengan Peraturan Menteri Negara Pemberdayaan Perempuan dan Perlindungan Anak Nomor 02 Tahun 2009.

Selama 30 tahun terakhir penelitian mengenai bagaimana menciptakan lingkungan yang baik bagi anak telah mengalami beberapa perubahan fokus penelitian. Sebelum tahun 1990, peneliti lebih banyak berfokus pada aspek keamanan dan desain dari sebuah lingkungan yang khusus sedangkan setelah tahun 1990 peneliti mulai mempertimbangkan faktor-faktor yang mempengaruhi anak dalam menggunakan lingkungan, daya tarik bagi anak untuk beraktivitas di luar ruangan, serta dampak aktivitas tersebut bagi perkembangan anak [2]. Lingkungan ramah anak yang baik tidak hanya harus memenuhi persyaratan teknis seperti keamanan, kenyamanan dan keindahan, tetapi juga harus menarik bagi anak sehingga anak mau menggunakannya. Perencanaan pembangunan yang mengedepankan anak sangat penting, mengingat bahwa kota yang memiliki proporsi penduduk anak tinggi justru berpotensi semakin tidak ramah anak, di mana kebutuhan dan prioritas anak seringkali terabaikan $[3,4]$. 
Tingginya tingkat urbanisasi menjadikan kota sebuah lingkungan yang padat lalu lintas, sesak, penuh polusi dan tekanan [5]. Anak membutuhkan ruang terbuka publik untuk melakukan aktivitas di luar ruang, bersosialisasi dengan teman sebaya dan berinteraksi dengan alam [2]. Beberapa tahun terakhir, telah banyak penelitian terkait penerapan konsep ramah anak pada taman sebagai ruang publik.

Baskara [6] dalam penelitiannya mengemukakan bahwa dalam perancangan taman ramah anak, harus memperhatikan keamanan, keselamatan, kemudahan, kenyamanan, keindahan dan kesehatan. Dewi [3] menambahkan bahwa taman bermain ramah anak juga memegang peranan dalam perwujudan Kota Layak Anak dalam aspek sosial, ekologikal, rekreasi dan pembelajaran bagi anak. Beberapa penelitian lain terkait taman ramah anak sebelumnya berupa evaluasi terhadap kinerja ruang terbuka publik ramah anak di beberapa kota seperti Jakarta [7], Palembang [8], Semarang [3]. Namun belum ada penelitian tentang pendapat pengguna taman terhadap prinsip-prinsip tersebut. Penelitian ini bertujuan untuk mengemukakan pendapat pengguna mengenai seberapa penting prinsip-prinsip taman ramah anak yang telah diungkapkan oleh penelitian-penelitian sebelumnya dan prinsip apa saja yang menurut pengguna mutlak dan mana yang dapat dikompromikan dalam taman ramah anak.

Kota Semarang sebagai ibukota Jawa Tengah seringkali menjadi barometer bagi perkembangan provinsi, salah satunya dalam penyediaan fasilitas ruang publik untuk anak berupa taman-taman yang baru dengan fasilitas untuk anak. Salah satu taman yang dirampungkan dalam dua tahun terakhir adalah Taman Citra Satwa yang terletak di Kelurahan Gayamsari. Meski tergolong baru, Taman Citra Satwa ramai dikunjungi tidak hanya oleh warga sekitar tetapi juga pengunjung yang rumahnya cukup jauh dari berbagai kalangan dan usia. Beberapa potensi dan daya tarik dari Taman Citra Satwa adalah letaknya yang berada tidak terlalu jauh dari pusat kota Semarang, dikelilingi kawasan permukiman, dan memiliki luasan $11.000 \mathrm{~m}^{2}$ lebih dengan fasilitas yang cukup lengkap tidak hanya untuk anak-anak tetapi juga untuk remaja dan orang dewasa. Sebagai sebuah taman baru yang diminati pengunjung, menarik untuk diteliti bagaimana pendapat pengguna taman terhadap prinsip taman ramah anak dan penerapan prinsip tersebut di dalam Taman Citra Satwa.

\section{Metode}

Penelitian ini bertujuan untuk menggali persepsi pengguna yaitu anak-anak dan orang tua yang mendampingi anak di taman terhadap prinsip taman ramah anak yang telah dirumuskan melalui kajian terhadap teori-teori dan hasil temuan penelitian sebelumnya. Untuk mencapai tujuan tersebut, peneliti menggunakan metode kualitatif dengan pendekatan rasionalistik. Menurut Muhadjir [9], pendekatan rasionalistik adalah pendekatan yang menekankan pada pemahaman intelektual dan logika dengan didukung data empirik yang relevan untuk menghasilkan grand concept penelitian. Pendekatan kualitatif digunakan untuk menggali lebih lanjut mengenai pendapat subjek penelitian dan informasi rinci mengenai tempat penelitian. Dalam penelitian ini, peneliti tidak melakukan rekayasa atau manipulasi terhadap keadaan di lapangan, namun sepenuhnya hanya berperan sebagai pengamat yang melakukan observasi, wawancara dan dokumentasi data [10]. 
Dalam menggali persepsi pengguna yaitu anak-anak dan orang tua yang mendampingi anak, peneliti menggunakan metode wawancara dengan pertanyaan tertutup dan pertanyaan terbuka. Pertanyaan tertutup digunakan untuk mengetahui pendapat pengguna mengenai seberapa penting masing-masing prinsip taman ramah anak, yaitu prinsip keamanan dan keselamatan, kenyamanan, kemudahan, daya tarik fasilitas, kesehatan dan kebersihan, kebutuhan sosial, dan pembelajaran di taman. Ketujuh prinsip tersebut didapatkan dari grand concept penelitian yang dirumuskan berdasarkan teori para ahli dan penelitian sebelumnya. Skala tingkat prioritas dinilai menggunakan skala likert dengan nilai 5 (lima) yaitu bila prinsip tersebut dianggap mutlak dan sangat harus terpenuhi, nilai 4 (empat) bila pengguna merasa lebih senang bila prinsip tersebut terpenuhi, nilai 3 (tiga) bila pengguna mengemukakan pendapat netral terhadap prinsip tersebut, nilai 2 (dua) bila pengguna menyatakan tidak terlalu memikirkan prinsip tersebut dan nilai 1 (satu) apabila prinsip tersebut dianggap tidak diperlukan. Pertanyaan tersebut diikuti pertanyaan terbuka untuk menggali lebih lanjut alasan dibalik penilaian oleh pengguna dan kondisi seperti apa yang diharapkan pengguna untuk dapat memenuhi kebutuhan dan mewujudkan prinsip-prinsip taman ramah anak tersebut.

Konsep ramah anak mengacu pada empat prinsip dasar yang dikemukakan pada Habitat II [11] yaitu kesamaan perlakuan untuk setiap anak, mengutamakan kepentingan anak, hak anak akan lingkungan dan kehidupan yang lebih baik, dan menghargai pendapat anak. Sebagai salah satu prinsip dasar ramah anak, perlibatan anak secara aktif dalam perancangan dan penyusunan kebijakan belum sepenuhnya terakomodasi. Rancangan maupun kebijakan disusun berdasarkan cara berpikir orang dewasa mengenai apa yang terbaik untuk anak ternyata tidak sama dengan apa yang benar-benar anak inginkan, bahkan terasa kaku dan membosankan [12]. Horelli [13] dalam penelitiannya di berbagai negara berkembang mengemukakan bahwa anak sesungguhnya telah dapat mengutarakan pendapatnya akan ruang yang mereka inginkan dan butuhkan. Beberapa tahun terakhir pelibatan anak telah mulai dilakukan oleh beberapa peneliti dengan berbagai teknik seperti membiarkan anak menggambar ruang yang mereka inginkan, mewawancarai mereka, dan memberikan kuesioner untuk melihat persepsi mereka terhadap rancangan dan kebijakan ramah anak [14]. Pada penelitian ini, wawancara ditujukan pada 20 pengguna taman berusia anak yaitu 6-18 tahun yang dianggap telah dapat mengutarakan pendapatnya dengan lebih jelas. Sementara untuk anak berusia lebih muda diwakilkan oleh 20 orang tua yang mendampingi anak.

Lokasi penelitian ini adalah Taman Citra Satwa yang merupakan salah satu taman dengan fasilitas anak di lokasi perumahan yang sekalipun masih baru beroperasi, telah banyak diminati oleh pengguna di Kota Semarang dan memiliki variasi pengunjung baik orang dewasa maupun anak-anak. Hal ini didukung oleh letaknya yang strategis dan luasan taman serta kelengkapan fasilitas yang beragam untuk pengguna dari berbagai usia dan latar belakang. Waktu yang dipilih untuk wawancara adalah sore di hari kerja antara pukul 16.00-18.00 dan akhir pekan pagi hari pukul 06.00-08.30 dan sore 16.00-18.00 yang merupakan waktu taman ramai dikunjungi. 


\section{Hasil Penelitian dan Pembahasan}

Taman Citra Satwa adalah salah satu taman dengan fasilitas anak yang berada di Kelurahan Pandean Lamper, Kecamatan Gayamsari, Kota Semarang. Taman ini dapat diakses dari Jalan Onta Raya yang merupakan jalan besar yang berdampingan langsung dengan Sungai Banjir Kanal Timur, dan dapat juga diakses dari sisi belakang taman yang merupakan perumahan penduduk (lihat Gambar 1). Taman ini dulu adalah lapangan kosong seluas lebih dari 11.000 $\mathrm{m}^{2}$ yang digunakan sebagai lapangan sepak bola oleh warga setempat. Pada tahun 2017 akhir, Taman Citra Satwa diresmikan dan mulai beroperasi.

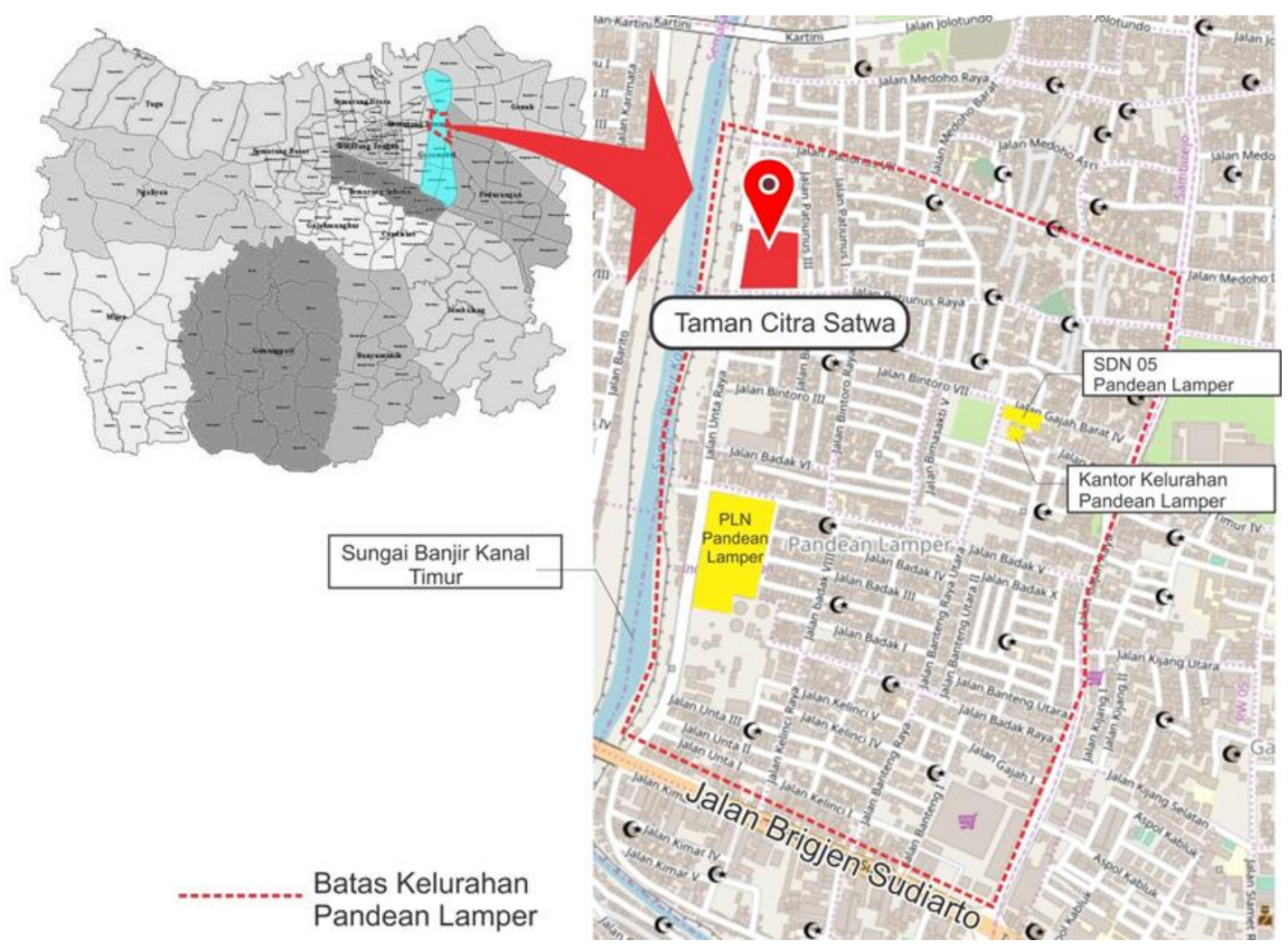

Gambar 1. Peta kawasan Taman Citra Satwa.

Sebagai salah satu taman di Kota Semarang yang memiliki luasan tanah yang sangat besar, Taman Citra Satwa dilengkapi berbagai fasilitas seperti lapangan sepak bola lengkap dengan, area duduk, area refleksi, area bermain anak, jogging track, taman hijau, dan patung-patung hewan yang menjadi daya tarik khas dari taman ini. Denah dan fasilitas dari Taman Citra Satwa dapat dilihat pada Gambar 2. 

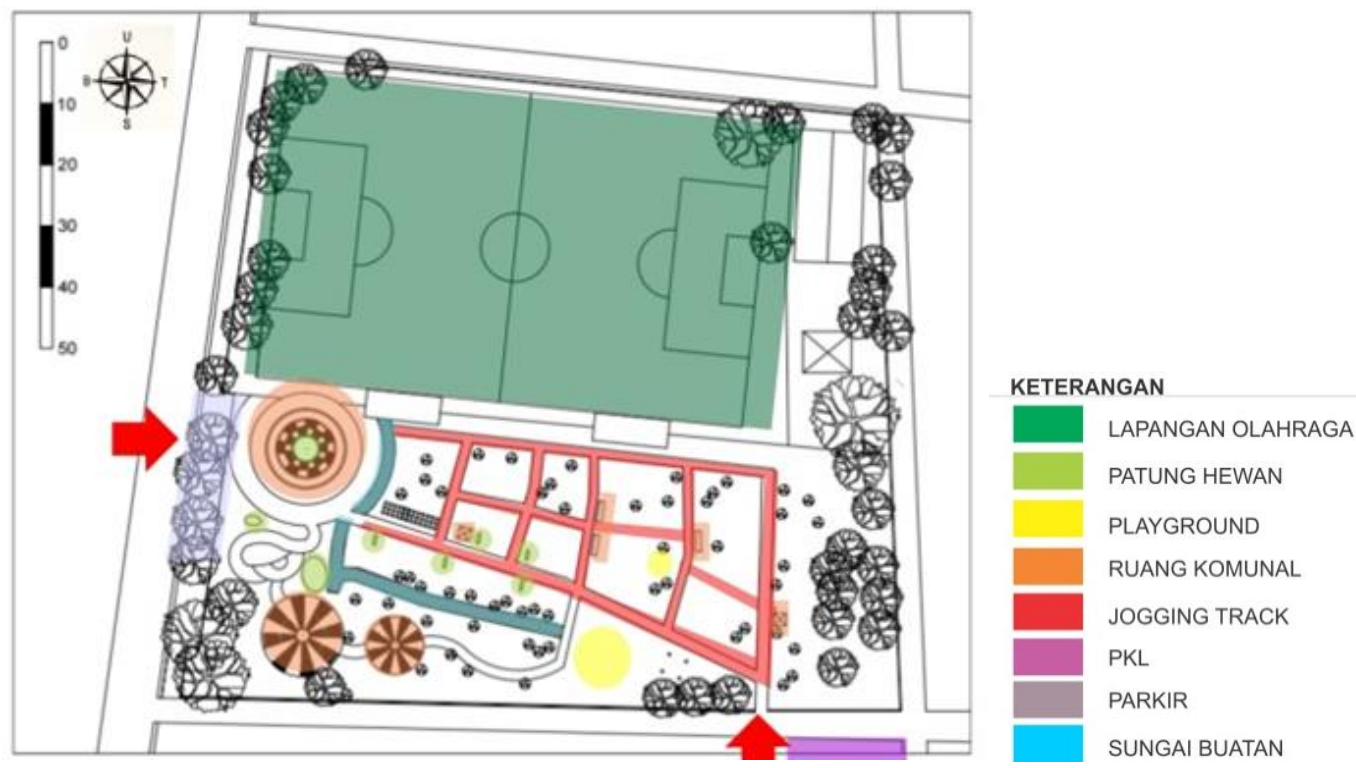

Gambar 2. Fasilitas di Taman Citra Satwa pada Tahun 2019.

Berdasarkan pengamatan di lapangan, diketahui bahwa pengunjung Taman Citra Satwa bervariasi dari usia bayi, anak-anak, remaja, orang dewasa, dan manula. Pengunjung terbanyak adalah anak-anak usia 6-12 dan anak-anak di bawah 6 tahun yang didampingi oleh orang tua atau pengasuhnya. Banyaknya anak di usia 6-12 tahun salah satunya disebabkan adanya kegiatan rutin latihan atau pertandingan persahabatan sepak bola di lapangan sepak bola yaitu dari beberapa klub sepak bola dan dari sekolah sebagai kegiatan ekstrakulikuler. Selain itu beberapa sekolah di sekitar Taman Citra Satwa rutin mengunjungi taman sebagai bagian dari jam pelajaran olahraga.

Selain aktivitas terjadwal, taman ini cukup ramai digunakan oleh anak-anak untuk bermain di area playground maupun sekedar berlarian di sekeliling taman. Di Taman Citra Satwa, selain alat permainan, patung hewan menjadi salah satu daya tarik bagi anak untuk memanjat dan menaikinya. Total patung hewan berjumlah 9 patung yaitu patung onta, angsa, gajah, badak, jerapah, kerbau, kancil, zebra dan kanguru. Dengan adanya patung Onta di pintu masuk utama taman ini, beberapa warga lebih akrab menyebut Taman Citra Satwa sebagai Taman Onta.

Aktivitas lain yang dapat dijumpai di taman ini adalah adanya anak-anak yang bersepeda di area jogging track, dan bagi anak-anak lebih muda yang belum bisa mengayuh sepeda beberapa orang tua mengajak anaknya menaiki kereta dorong atau sepeda atau mobil yang dapat didorong. Pengunjung berusia remaja juga dapat dijumpai di taman ini meski tidak sebanyak anak-anak yang lebih muda. Kebanyakan remaja memilih untuk duduk-duduk bergerombol sembari mengobrol atau membaca buku. Dapat juga dijumpai remaja pria dan wanita yang duduk berdua di area duduk tersebut. Pengunjung berusia dewasa di taman biasanya adalah orang tua yang sekalian mengantar dan menemani anaknya bermain atau menunggu anaknya berlatih sepak bola. Sementara pengunjung berusia lansia lebih sering berkunjung ke taman di pagi hari untuk refleksi kaki dan berolahraga jalan santai. 
Taman Citra Satwa sebagai ruang publik menjadi tempat berkumpul, bersosialisasi, berolahraga, bermain, dan sebagai sarana rekreasi yang dinikmati oleh tidak hanya anak-anak kecil, namun juga remaja, dan orang tua. Dewi [3] mengemukakan bahwa taman bermain ramah anak memegang peranan dalam aspek sosial, ekologikal, rekreasi dan pembelajaran. Dalam ranah sosial, taman berperan sebagai tempat di mana anak dapat bermain dengan bebas, bertemu dengan teman dan bersosialisasi dengan orang lain. Secara ekologikal, taman harus dapat menyediakan lingkungan yang sehat bagi anak, dengan vegetasi yang cukup dan udara yang segar. Taman juga harus dapat memberikan unsur rekreatif, yaitu bahwa lingkungan taman tersebut nyaman bagi anak, teduh, bebas dari gangguan sekitar seperti polusi dan sampah serta dilengkapi dengan fasilitas pendukung yang dapat memenuhi kebutuhan dan minat anak. Aspek rekreasi ini erat kaitannya dengan kenyamanan anak ketika beraktivitas di taman. Sebagai sarana edukasi, taman memberikan unsur pembelajaran, yaitu bahwa taman menjadi tempat anak untuk menemukan dan mengalami hal-hal baru.

Dalam penyelenggaraan taman bagi anak-anak, Baskara [6] menyampaikan ada beberapa prinsip yang harus diperhatikan. Keselamatan anak di taman harus terjaga, yaitu desain taman tidak boleh menimbulkan resiko kecelakaan pada anak saat bermain. Keamanan anak juga harus terjamin dengan desain taman yang meminimalisir resiko terjadinya tindakan kriminal atau penculikan terhadap anak. Kesehatan anak baik dalam jangka pendek maupun jangka panjang tidak terganggu akibat bermain di taman. Selain itu, desain harus dapat memberikan rasa nyaman baik secara psikologis seperti rasa aman, tidak terganggu dan secara fisik seperti suhu udara dan keteduhan. Desain taman juga harus dapat mudah diakses, dipahami dan digunakan oleh semua anak termasuk anak disabilitas. Di samping semua prinsip tadi, taman juga harus tetap menarik bagi anak untuk datang dan menggunakannya.

Dalam penelitian ini, prinsip taman ramah anak yang digunakan sebagai grand concept yang mengacu pada penelitian Baskara [6] dan Dewi [3] yaitu (1) keamanan dan keselamatan, (2) fungsi rekreasi atau kenyamanan, (3) kemudahan aksesibilitas, (4) daya tarik taman, (5) kesehatan, (6) memenuhi kebutuhan sosial dan (7) adanya unsur pembelajaran ketika anak beraktivitas di taman. Dari hasil wawancara dengan pengguna ditemukan bahwa prinsip kesehatan merupakan yang paling penting dan mutlak harus terpenuhi di taman. Prinsip yang dianggap penting selanjutnya adalah prinsip daya tarik taman, keamanan dan keselamatan, kenyamanan, kebutuhan sosial, pembelajaran dan terakhir adalah prinsip kemudahan akses pada taman sebagaimana dapat dilihat pada Gambar 3 sebagai berikut. 


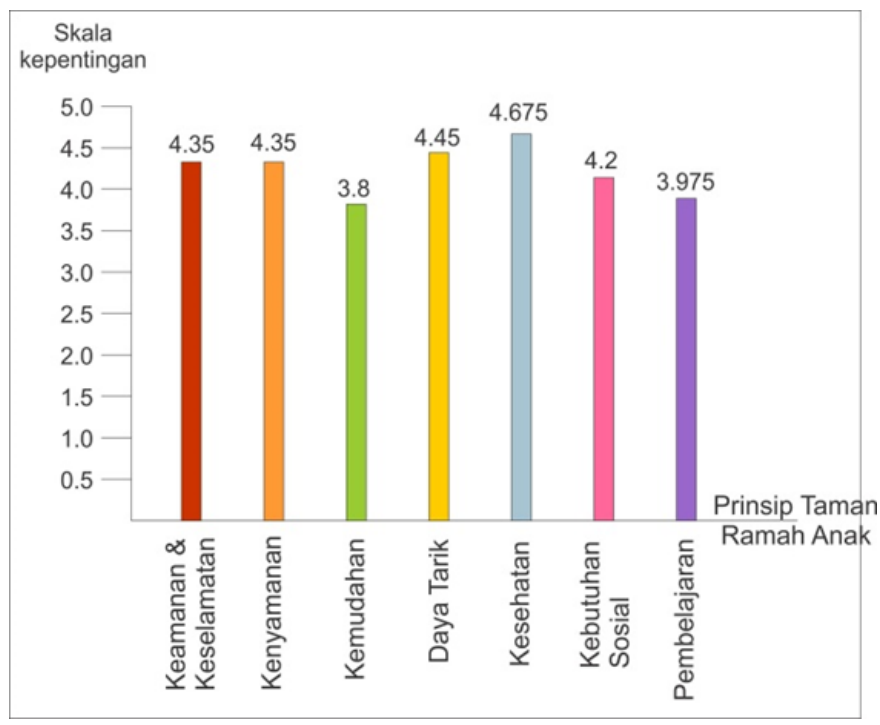

Gambar 3. Penilaian pengunjung terhadap prinsip taman ramah anak.

\subsection{Kesehatan}

Beraktivitas di ruang terbuka membuat anak dapat menikmati suasana yang lebih sehat, alamiah, dengan udara segar yang baik bagi kesehatan anak [4]. Sebagaimana dinyatakan oleh Worpole dalam Open Space People Space [15], bahwa kesehatan masyarakat adalah hukum tertinggi, dan karenanya penyediaan ruang publik yang sehat berkaitan erat dengan kesehatan publik. Beberapa indikator dari prinsip kesehatan anak di taman menurut Baskara [6] dan CPSC [16] yaitu:

- Lokasi taman tidak berada pada area dengan polusi udara, air, bunyi dan penciuman (bau) yang dapat mempengaruhi aktivitas bermain anak

- Adanya larangan merokok di dalam taman

- Adanya peneduhan agar anak tidak terus-menerus terpapar sinar matahari yang dapat menyebabkan pusing atau masalah kulit.

Dari hasil wawancara, ditemukan bawaha pengguna Taman Citra Satwa baik anak-anak dan orang tua bersepakat bahwa lingkungan taman seharusnya bebas dari polusi dan ancaman gangguan kesehatan lainnya seperti asap rokok, sampah, dan debu. Dari 40 sampel, 100\% menyatakan tetap keberatan ke taman semenarik apapun apabila di dalamnya banyak orang yang merokok. Alasan yang paling umum disampaikan adalah asap rokok dapat membuat anak batuk, sakit mata, bau, dan ketidaknyamanan psikologis. Tingkat keberatan paling tinggi dinyatakan oleh orang tua yang menemani anak usia dini, dan anak-anak pra remaja. Sementara beberapa anak yang lebih besar menyatakan tetap keberatan, namun masih dapat memutuskan untuk menghindari area-area tertentu yang berasap. Pengguna taman menyatakan bahwa taman yang luas seperti di Taman Citra Satwa memberikan lebih banyak area bagi pengguna untuk menghindari sumber polusi di taman. 
Vegetasi untuk peneduhan di Taman Citra Satwa saat ini dinyatakan masih sangat kurang oleh pengguna taman, namun lebih berdampak pada kurangnya kenyamanan dan belum dirasa membahayakan kesehatan karena mayoritas pengguna taman menggunakan taman hanya di waktu pagi dan sore hari. Dua puluh persen pengguna mengeluhkan kondisi tanah di Citra Satwa yang tidak sepenuhnya tertutup rumput sehingga saat musim kering banyak debu tanah yang berterbangan. Permukaan tanah yang tidak rata di taman menimbulkan genangan air (Gambar 4) dan adanya sungai yang tidak mengalir di Taman Citra Satwa juga dikhawatirkan pengguna menyebabkan banyaknya nyamuk di taman menjelang malam hari (Gambar 5). Sungai tersebut pada awalnya memiliki pompa untuk mengalirkan air dari satu sisi ke sisi lain dan membuangnya keluar taman, namun menurut pengguna taman pompa tersebut telah lama tidak beroperasi.

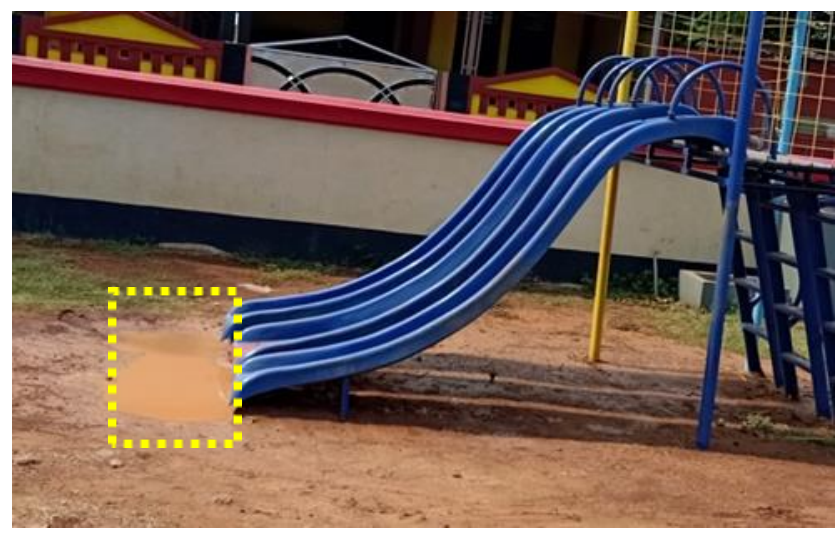

Gambar 4. Genangan air saat musim hujan di area bermain Taman Citra Satwa.

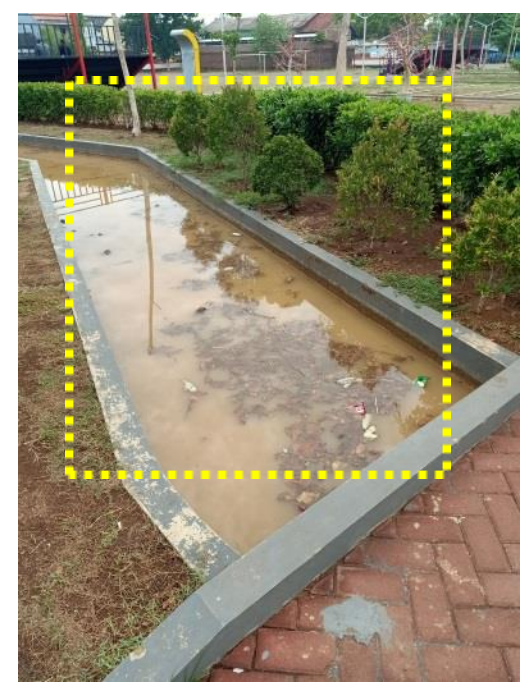

Gambar 5. Air sungai buatan di Taman Citra Satwa tidak mengalir dan berpotensi menjadi sarang jentik nyamuk.

Mayoritas pengunjung taman berpendapat bahwa tujuan mereka ke taman adalah untuk menikmati udara segar dan refreshing, karenanya prinsip bahwa taman ramah anak harus sehat adalah hal yang harus diutamakan $[4,17]$. Dari hasil wawancara ditemukan bahwa desain taman yang berpengaruh terhadap prinsip kesehatan di taman ramah anak menurut pengguna adalah ada atau tidaknya larangan merokok, tidak banyak material permukaan yang mudah tertiup angin seperti tanah atau pasir, dan saluran pembuangan air yang baik.

\subsection{Daya tarik fasilitas taman}

Dalam mengelola lingkungan binaan bagi anak salah satu hal yang harus diperhatikan adalah selera anak. Agar menarik bagi anak, maka penyediaan dan pengemasan lingkungan harus mempertimbangkan minat dan dinamika perkembangan anak $[6,18]$, antara lain:

- Penggunaan warna-warna kontras dan mencolok yang disukai anak. 
- Penerapan bentuk-bentuk yang bersifat imajinatif, atau bentuk yang menimbulkan penciptaan karakter pada tokoh-tokoh yang digemari anak namun tetap harus mewakili pesan-pesan pembelajaran.

- Ukuran alat permainan memperhitungkan ketinggian dan ukuran yang sesuai dengan tubuh anak.

- Fasilitas permainan yang tidak terlalu rumit namun memberikan tantangan bagi anak. Selain itu juga dapat melatih motorik kasar/halus sesuai kemampuan anak.

- Pilihan variasi, fasilitas yang kaya dan bervariasi akan lebih memungkinkan untuk memenuhi kebutuhan anak.

Pengunjung Taman Citra Satwa menyatakan bahwa prinsip kedua yang diprioritaskan adalah daya tarik fasilitas. Prinsip ini bahkan dianggap lebih penting oleh beberapa anak dibandingkan keamanan atau kenyamanan sekalipun.

"Yang penting ada mainan yang sangat banyak."

-seorang anak 8 tahun

"Di rumah bosan, makanya ke taman, soalnya banyak yang menarik di taman."

-seorang anak 14 tahun

Anak-anak menyatakan bahwa hal yang membuat mereka tertarik untuk datang ke Taman Citra Satwa tidak hanya berupa mainan, tetapi juga adanya fasilitas olahraga, adanya aktivitas yang bisa dilihat seperti latihan sepak bola, penataan vegetasi yang cantik untuk berswafoto (Gambar 6).

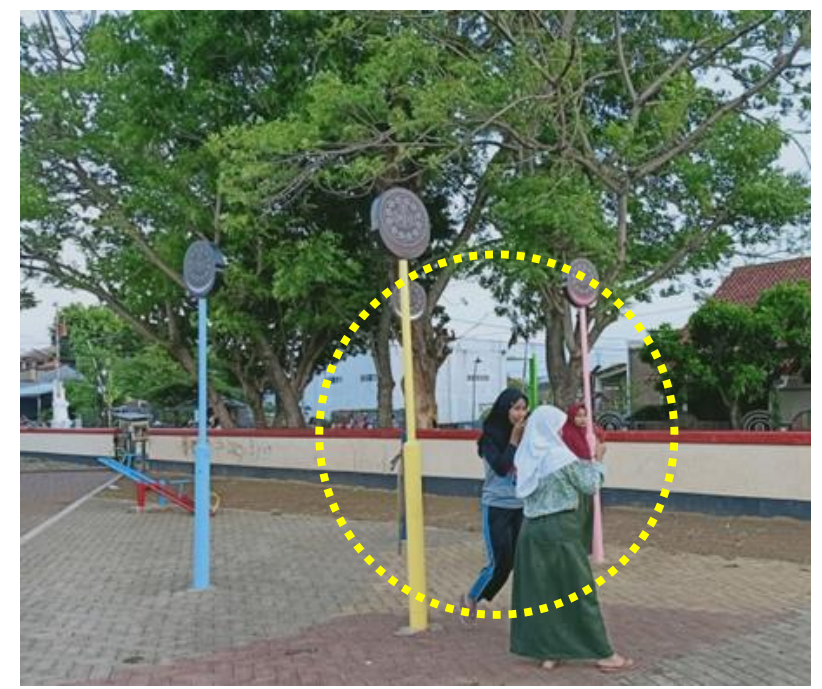

Gambar 6. Beberapa anak remaja sedang foto bersama dengan latar belakang taman.

Selain itu pengguna juga menyatakan bahwa ada atau tidaknya layanan wi-fi gratis dapat menjadi daya tarik lebih bagi sebuah taman. Orang tua yang mendampingi anak usia dini 
menyatakan bahwa di Taman Citra Satwa, ukuran alat permainan belum sesuai untuk anakanak di bawah 3 tahun, dan orang tua harus selalu mendampingi dan memegang anak agar stabil. Bagi anak usia dini yang belum dapat secara maksimal menggunakan alat permainan, luasnya lapangan untuk berlarian dan adanya patung-patung hewan menjadi daya tarik yang lebih kuat. Anak-anak menyukai berada di dekat patung hewan, memanjat, dan berfoto di patung hewan (Gambar 7). Dari hasil wawancara tersebut, terlihat bahwa anak-anak dari berbagai tingkatan usia memiliki kebutuhan dan minat yang berbeda tentang fasilitas apa yang menarik bagi mereka di taman.

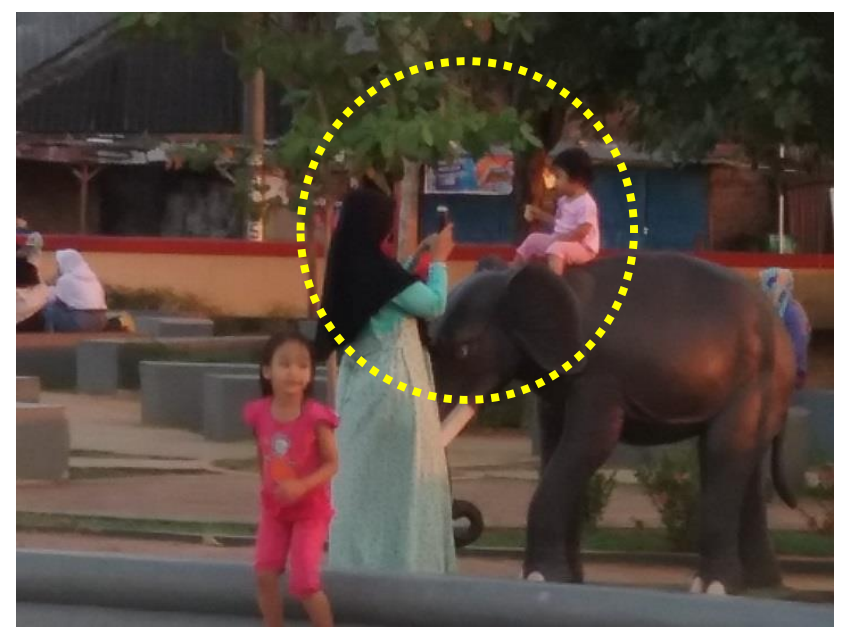

Gambar 7. Seorang pengguna taman sedang memotret anaknya yang duduk di atas patung Gajah.

\subsection{Kenyamanan}

Kenyamanan berbicara mengenai kondisi dimana anak tidak merasa terganggu dalam beraktivitas bermain. Indikator aspek kenyamanan menurut Baskara [6] dan Hernowo [14], yaitu:

- Lokasi taman tidak terletak dekat dengan kegiatan atau fungsi lain yang mengganggu seperti tempat pembuangan sampah, pabrik, pusat keramaian.

- Lingkungan memiliki cukup ruang hijau dan pepohonan sebagai peneduh

- Kelengkapan fasilitas dan area untuk beristirahat

- Fasilitas sanitasi yang memadai seperti kamar mandi

- Penataan letak di taman memberikan ruang untuk anak bebas bergerak, tidak terasa sesak.

- Lingkungan dan fasilitas bersih dan terawat

Pengguna mengemukakan bahwa taman yang nyaman menurut pengunjung adalah taman yang teduh dan memberikan suasana yang asri sehingga mereka dapat merasa lebih santai di taman. Selain itu kecukupan fasilitas untuk beristirahat juga menjadi faktor penting dalam mewujudkan kenyamanan di taman. 


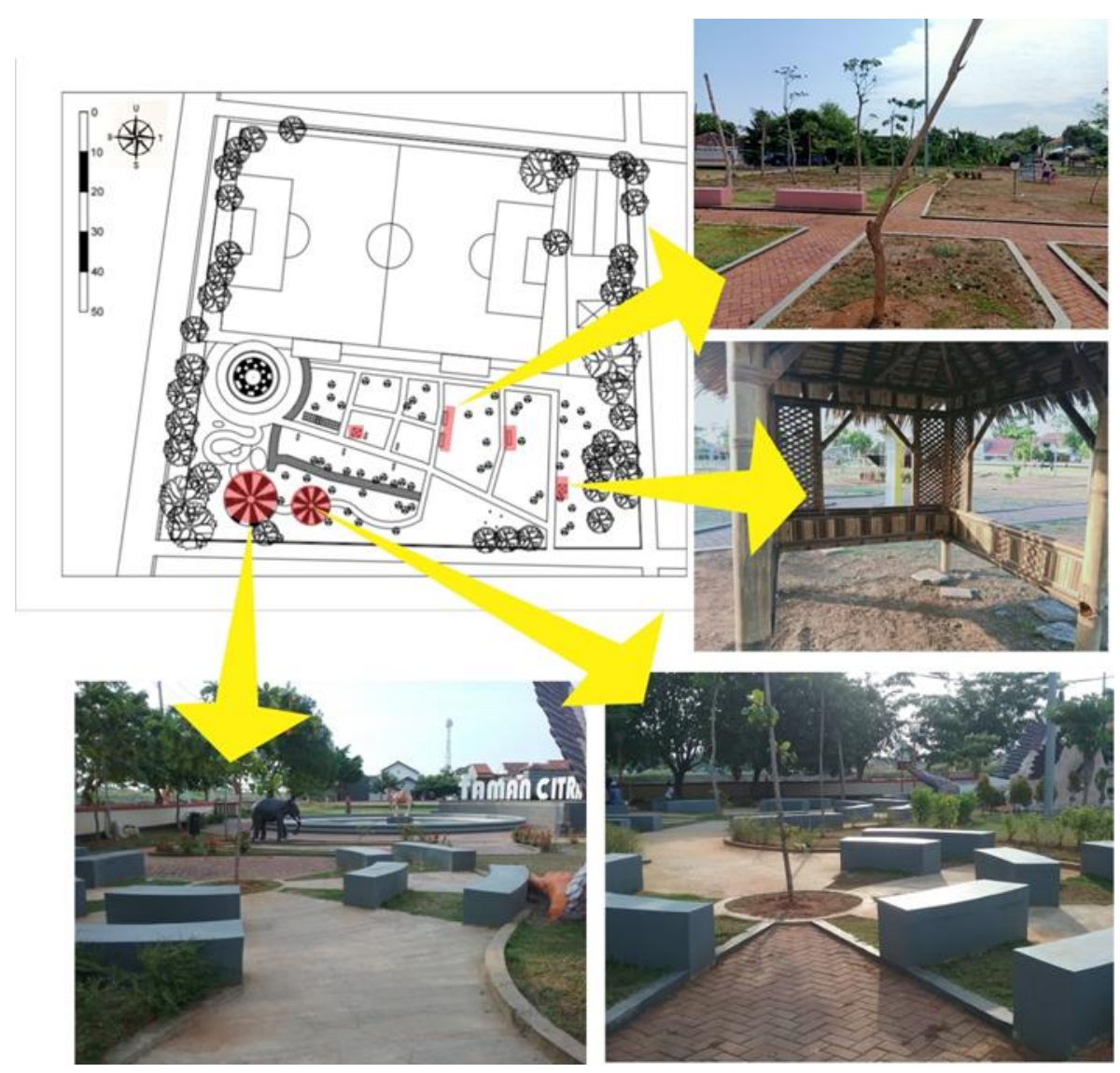

Gambar 8. Fasilitas tempat duduk pada Taman Citra Satwa.

Di Taman Citra Satwa, tempat duduk yang cukup banyak dapat ditemukan di area barat taman (Gambar 8), namun belum banyak fasilitas tempat duduk di bagian lain dari taman. Dan bila ada fasilitas tempat duduk berupa saung, fasilitas tersebut tidak terawat dengan baik sehingga tidak dapat digunakan dengan maksimal. Selain saung, seluruh tempat duduk di Taman Citra Satwa tidak memiliki peneduh baik peneduh permanen seperti pergola ataupun peneduh alami seperti pohon. Oleh karena itu, tempat duduk terasa tidak nyaman ketika hari mulai siang, dan akan basah di pagi hari ketika malam sebelumnya turun hujan. Bagi pengguna taman, tidak hanya jumlah fasilitas tempat duduk yang mencukupi, namun persebaran tempat duduk yang merata, serta situasi dan keteduhan area duduk mempengaruhi bagian taman mana yang lebih sering dilewati dan seberapa lama mereka berada di taman. Kenyamanan menjadi salah satu faktor penting yang membuat aktivitas pengunjung di taman tidak terganggu dan merasa betah berada di taman untuk waktu yang cukup lama sebagaimana dikemukakan oleh Baskara [6].

\subsection{Keamanan dan keselamatan}

Dalam menyediakan fasilitas untuk anak, salah satu aspek yang harus diperhatikan adalah keamanan dan keselamatan anak. Keamanan adalah kondisi terhindar dari bahaya tindak kriminalitas seperti penculikan dan penindasan (bullying). Keselamatan adalah kondisi aman dari bahaya kecelakaan seperti terjepit, terjatuh, dan tertabrak. Ada empat hal yang harus 
diperhatikan dalam penataan dan perancangan taman bermain bagi anak [16], yaitu sebagai berikut:

- Lokasi tidak berdekatan dengan potensi bahaya seperti sungai, jalan raya

- Adanya cukup peneduh di area bermain sehingga alat permainan tidak menjadi panas dan anak tidak terpapar matahari secara terus menerus dan menjadi pusing. [19]

- Adanya pemisahan area bermain berdasarkan usia, juga antara permainan aktif dan pasif.

- Kemudahan pengawasan oleh orang tua

- Alat permainan tidak tajam dan terawat

- Permukaan di bawah area bermain lembut

- Adanya pengawas taman dan CCTV

Orang tua yang mendampingi anak di bawah 6 tahun mengemukakan bahwa keamanan dan keselamatan yang terutama adalah kemudahan untuk mengawasi anak. Beberapa pengguna setuju bahwa adanya pagar pembatas di Taman Citra Satwa memberi rasa aman bahwa anak tidak akan mudah berlari ke jalan (Gambar 9). Pengguna juga mengemukakan harapan mereka akan adanya pemisahan area anak kecil dan yang lebih besar, serta pemilihan material permukaan yang lebih lembut untuk area bermain, namun kebanyakan menyatakan bahwa seperti apapun desain pengamanan yang direncanakan, mereka akan tetap mengawasi anakanak terutama di usia dini. Beberapa pengguna menyatakan desain Taman Citra Satwa yang luas dan terbuka memudahkan orang tua untuk mengawasi dan mengikuti anak ketika bermain. Sementara anak-anak dan remaja yang diwawancara menyatakan tidak terlalu khawatir akan terluka atau mengalami kecelakaan, namun lebih mengkhawatirkan apabila diganggu orang jahat atau oleh kelompok anak-anak yang tidak dikenal. Anak-anak yang lebih dewasa menyatakan bahwa mereka merasa cukup aman apabila taman tersebut cukup ramai, terbuka, dan dekat dengan rumah. Adanya pengawas dan CCTV juga dinyatakan dapat membantu memberi rasa aman, namun yang terutama adalah apabila mereka telah cukup akrab dengan lingkungan dan berada di tengah banyak orang.

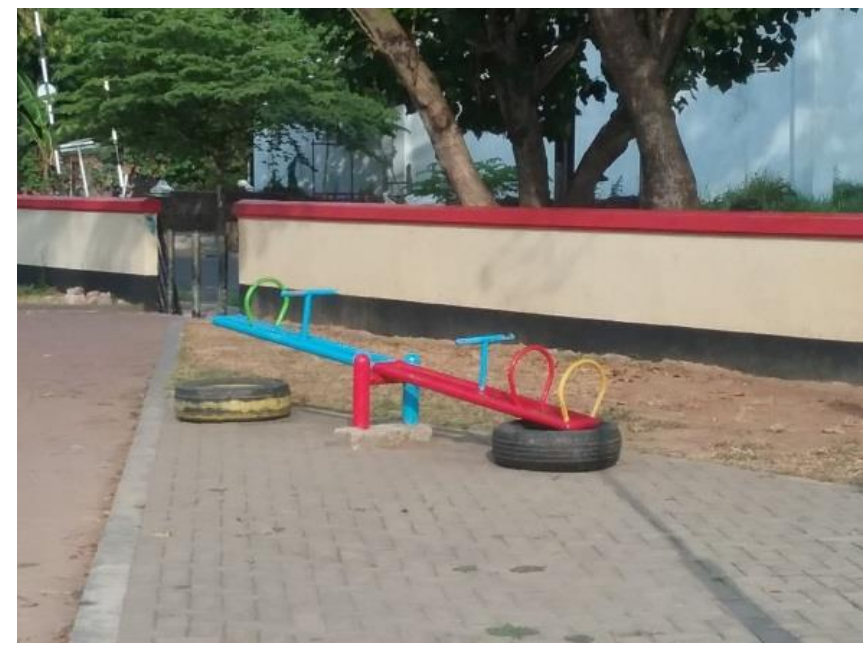

Gambar 9. Pagar di sekeliling Taman Citra Satwa. 
Perencanaan taman bermain ramah anak harus mempertimbangkan keamanan dan keselamatan anak, mengingat anak usia dini belum dapat menguasai dirinya dengan baik (Baskara, 2010). Oleh karena itu, kemudahan pengawasan tetap menjadi prioritas utama. Sementara untuk anak yang lebih besar, desain pengamanan khusus seperti yang disebutkan dianggap tidak terlalu dibutuhkan lagi.

\subsection{Kebutuhan sosial}

Taman merupakan wadah bagi anak untuk melakukan aktivitas ruang luar, bermain, berolahraga dan bersosialisasi. Anak-anak dapat bertemu dengan teman sebaya mereka dan melakukan aktivitas bersama yang meningkatakan kemampuan berbicara serta bagaimana menyampaikan pendapat dengan baik ke orang lain yang terutama dipelajari oleh anak yang lebih muda [20]. Menurut Travlou dalam Open Space People Space [15], bagi anak muda, taman sebagai ruang publik juga menjadi tempat di mana anak mereka bisa sejenak terbebas dari pengawasan orang dewasa yang membuat mereka merasa lebih bebas, rileks dan dapat mengekspresikan diri. Adanya interaksi sosial di taman merupakan salah satu faktor penarik bagi orang tua maupun anak untuk datang ke taman. Menurut Aziz dan Said [2] dan Refshauge et al [21], timbulnya interaksi sosial di taman dipengaruhi beberapa aspek, antara lain:

- Lokasi berada di dekat area permukiman dan tidak terlalu padat

- Ada teman yang dikenal

- Taman tidak penuh sesak tetapi juga tidak sepi

- Kecukupan penerangan dan kemudahan pengawasan oleh pengelola maupun masyarakat

- Adanya fasilitas yang mendukung terciptasnya interaksi seperti kursi taman, gazebo, area peneduh, kantin

- Kualitas lingkungan hijau yang memberi keteduhan dan kenyamanan dalam bersosialisasi

Orang tua yang mendampingi anaknya di Taman Citra Satwa menyatakan dengan sengaja membawa anaknya ke taman agar anaknya dapat bertemu dengan teman sebayanya. Sebanyak $90 \%$ orang tua merasa senang bila anaknya bisa bergaul dengan anak-anak lain di taman. Selain alat permainan seperti ayunan dan jungkat-jungkit, anak-anak dapat menikmati aktivitas bersama dengan menciptakan aturan permainan mereka sendiri di Taman Citra Satwa (Gambar 10). Bagi anak-anak terutama yang lebih muda, interaksi dengan anak lain tidak berarti harus bermain bersama, tetapi dapat juga dalam bentuk mengamati aktivitas anak lain dan menirunya. Dengan melihat bagaimana cara anak lain bermain dan bersosialisasi, anak mendapatkan model cara bersosialisasi di masyarakat dan belajar untuk lebih berani. Bagi anak-anak yang lebih dewasa, aktivitas di taman sangat erat kaitannya dengan keberadaan teman, 95\% responden menyatakan bahwa mereka menikmati aktivitas di taman bersama teman, dan bahkan beberapa menyatakan tidak akan ke taman bila tidak bersama teman. 


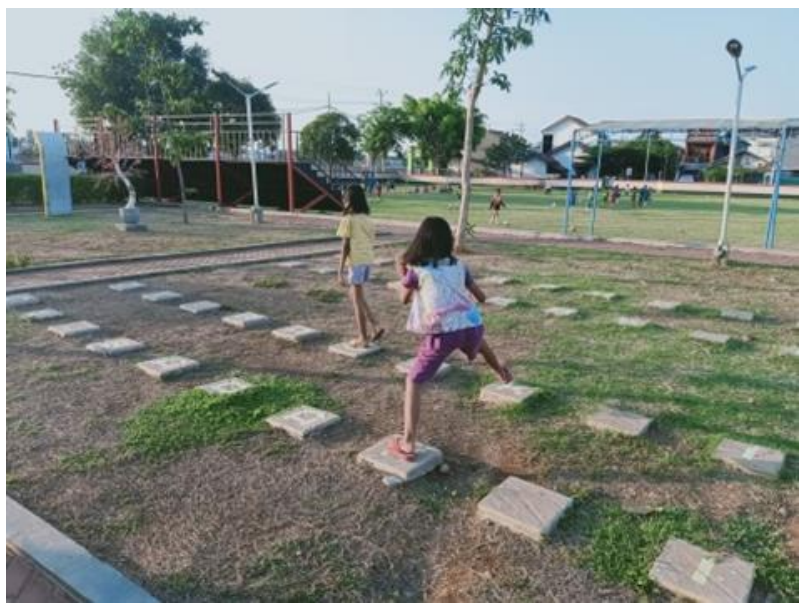

Gambar 10. Anak bergaul dan bermain bersama di Taman Citra Satwa.

"Di taman bisa ketemu teman sepuasnya. Dan gak diawasin orang tua."

-seorang anak 10 tahun

Dapat dilihat bahwa taman kini menjadi sebuah wadah yang dianggap nyaman, bebas, dan gratis untuk anak bertemu dengan teman sebayanya, di mana mereka bisa lebih bebas berekspresi tanpa merasa diawasi oleh orang dewasa [15].

\subsection{Kemudahan akses}

Taman sebagai sebuah ruang publik harus dapat diakses dengan mudah oleh semua kalangan masyarakat. Selain kemudahan pencapaian, kemudahan pengguna bergerak dari satu area ke area lain di dalam taman adalah salah satu prinsip taman yang harus diperhatikan. Beberapa indikator kemudahan aksesibilitas di taman menurut Perry et al [22], Baskara [6], dan Hernowo [14] adalah sebagai berikut:

- Taman cukup dekat dan mudah diakses oleh anak dari semua latar belakang termasuk anak dengan keterbatasan

- Sarana menuju taman mudah dilewati baik dengan berjalan maupun kendaraan

- Pintu masuk taman mudah terlihat dan dikenali

- Sirkulasi di dalam taman mudah dilalui oleh anak dari semua usia dan latar belakang 

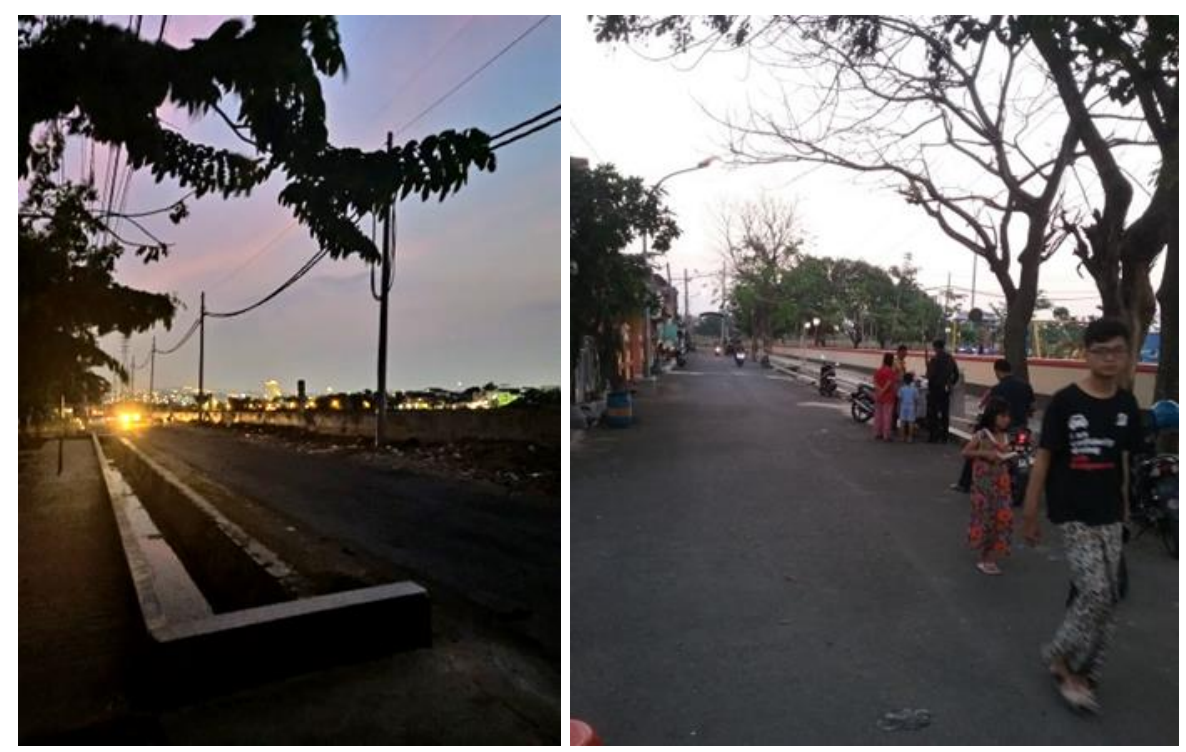

Gambar 11. Jalan menuju Taman Citra Satwa.

Di Taman Citra Satwa, anak-anak dan orang tua menyatakan setuju bila ada taman yang lebih dekat ke rumah mereka sehingga mudah untuk dicapai, namun mayoritas tidak keberatan bila harus menempuh perjalanan sedikit lebih jauh untuk ke taman, selama mereka merasa bahwa taman tersebut cukup menarik dan nyaman untuk mereka. Dari 40 responden, $15 \%$ berjalan kaki menuju Taman Citra Satwa, $22.5 \%$ orang menaiki sepeda, dan sisanya menggunakan kendaraan bermotor menuju taman, bahkan apabila rumah mereka terbilang tidak terlalu jauh dari taman. Sekalipun jalan utama menuju taman tidak dilewati jalur kendaraan umum, pengguna taman menyatakan jalan menuju Taman Citra Satwa cukup besar dan mudah untuk dilewati baik dengan berjalan kaki, mengendarai motor maupun mobil (Gambar 11). Taman Citra Satwa tidak memiliki area khusus untuk parkir mobil, sehingga pengguna taman memarkir mobil mereka di badan jalan di sekeliling taman. Area parkir motor terdapat di pintu masuk utama taman yang cukup luas (Gambar 12).

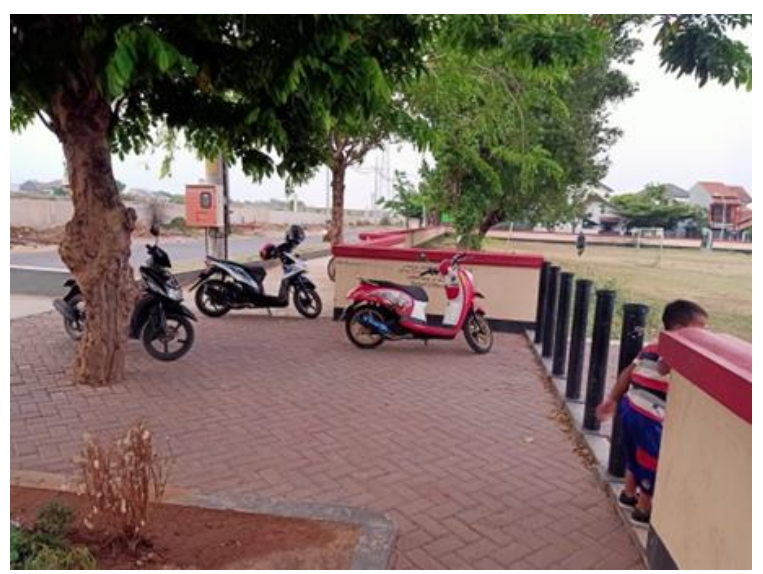

Gambar 12. Area parkir motor di Taman Citra Satwa.

Received: December 12, 2019; Accepted: January 30, 2020; Available online: July 15, 2021 


\subsection{Pembelajaran}

Kesempatan untuk berada di ruang publik penting bagi perkembangan anak baik dari perkembangan motorik maupun secara kognitif dan psikososial anak [23]. Ketika berada di ruang publik, kecerdasaan anak terstimulasi melalui pengalaman ruang ketika melihat, menyentuh, merasakan, mendengar dan mencium. Piaget dalam Mariyana [18] menyatakan bahwa perkembangan anak terjadi melalui keterlibatan aktif dengan lingkungannya, di mana anak-anak mengolah pengalamannya secara terus-menerus dan menyusunnya ulang dalam struktur mentalnya. Salah satu cara pembelajaran anak yang paling menonjol adalah dengan aktivitas bermain, karenanya peranan bermain telah menjadi salah satu topik sentral dalam pembahasan lingkungan ruang terbuka bagi anak [24]. Menurut Dariyo dalam Muthmainnah [25] aktivitas bermain dapat mendorong anak untuk lebih mudah beradaptasi dan belajar untuk mengekspresikan pikiran dan perasaannya sehingga menunjang perkembangan psikoemosional anak. Beberapa indikator taman bermain yang mendukung pembelajaran anak antara lain:

- Desain taman yang memicu daya imajinasi, kreativitas dan menyesuaikan dengan kesukaan anak

- Desain taman yang memiliki tahapan tantangan untuk anak sesuai kemampuan

- Desain taman yang memiliki tahapan tantangan bagi anak

- Desain taman dan alat permainan yang melibatkan ketrampilan sensorik dan motorik halus anak

- Taman memiliki area untuk aktivitas individual dan aktivitas kelompok

- Taman memiliki fasilitas untuk anak dari berbagai kelompok umur baik anak usia dini maupun anak yang lebih besar

- Adanya aktivitas terjadwal yang memicu kreativitas anak

Prinsip terakhir yang diprioritaskan oleh pengguna taman adalah pembelajaran. Faktor pembelajaran lebih banyak ditemukan pada anak-anak yang berusia lebih muda. Hal ini dinyatakan oleh orang tua yang mendampingi mereka, bahwa di Taman Citra Satwa, anak-anak senang dan bisa belajar mengenal bentuk hewan karena adanya patung-patung hewan (Gambar 13). Hal-hal lain yang dianggap dapat menjadi sarana pembelajaran untuk anak di Taman Citra Satwa adalah kekayaan aktivitas seperti latihan sepak bola, orang berlari, orang bersosialisasi, yang didukung oleh ragam fasilitas dan alat permainan.

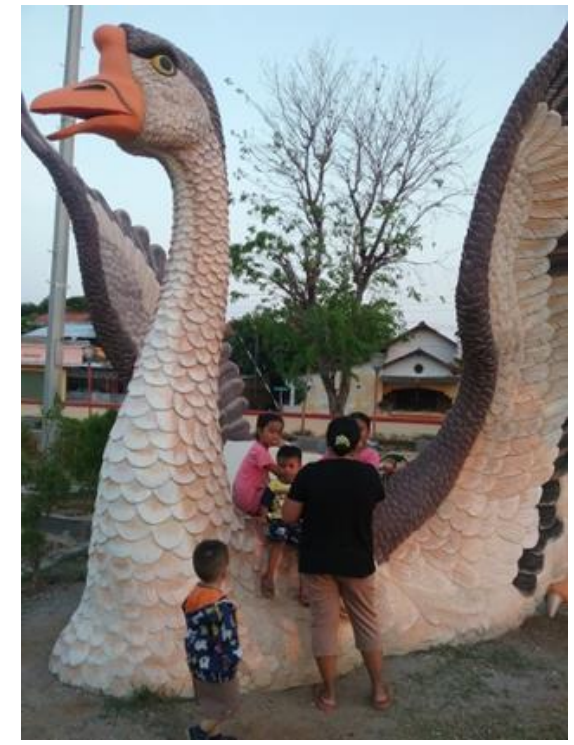

Gambar 13. Patung hewan di Taman Citra Satwa menjadi daya tarik bagi anak-anak. 


\section{Kesimpulan}

Dalam perencanaan fasilitas taman yang ramah anak, penting untuk melibatkan pendapat pengguna, yaitu bagaimana mereka beraktivitas serta bagaimana mereka memandang ruang taman dan potensinya. Hasil dari penelitian ini menunjukkan bahwa prinsip taman ramah anak yang paling diprioritaskan oleh pengguna yaitu: (1) kesehatan, (2) daya tarik, (3) keamanan dan keselamatan, (4) kenyamanan, (5) kebutuhan sosial, (6) kemudahan, dan (7) pembelajaran.

Sebuah taman ramah anak tidak cukup berhenti pada perancangan yang memenuhi standar regulasi, tetapi juga harus menarik pengguna untuk beraktivitas di dalamnya dan merasa betah ketika beraktivitas. Taman merupakan fasilitas publik yang terkait erat dengan lingkungan yang asri dan sehat, di mana pengunjung mengharapkan dapat menikmati udara segar dan merasa lebih santai di taman. Faktor kesehatan seperti kebersihan udara dan larangan merokok menjadi hal yang sangat penting untuk diperhatikan dalam perancangan taman bermain ramah anak. Prinsip selanjutnya yang harus diperhatikan adalah bagaimana taman dapat menarik pengguna dari kalangan usia dan latar belakang yang lebih beragam. Faktor daya tarik sebuah taman menjadi kunci apakah taman tersebut akan digunakan secara aktif atau tidak. Taman harus cukup nyaman agar pengguna dapat menikmati aktivitas dengan cukup lama di dalamnya. Kenyamanan tersebut dapat dicapai dengan lingkungan yang asri dan teduh serta kecukupan fasilitas. Desain taman yang mengutamakan keamanan dan keselamatan di taman menjadi prioritas terutama bagi orang tua dengan anak-anak yang lebih muda, sementara bagi anak yang lebih dewasa tidak lagi diperlukan desain khusus seperti pagar maupun penggunaan material yang lembut. Pengguna taman saat ini banyak yang menggunakan kendaraan bermotor untuk mencapai taman, sehingga jarak tidak lagi menjadi aspek yang sangat penting. Namun kedekatan jarak taman ke rumah tetap menjadi hal yang lebih diinginkan oleh sebagian besar pengunjung taman. Taman menjadi wadah bagi anak untuk bersosialisasi dengan melihat anak lain, anak yang lebih muda dapat belajar bagaimana cara bersosialiasasi di masyarakat. Sementara bagi anak yang lebih dewasa, taman menjadi tempat di mana mereka bisa lebih bebas bertemu dengan teman di luar pengawasan orang dewasa. Aktivitas di taman selain berdampak positif dalam memenuhi kebutuhan sosial anak, juga memberikan aktivitas pembelajaran dengan memperkenalkan bentuk dan hal-hal baru yang tidak dapat mereka jumpai di rumah atau di sekolah.

Dari hasil penelitian ini ditemukan bahwa anak-anak dari berbagai tingkatan usia memiliki kebutuhan akan rasa aman dan rasa nyaman, perilaku sosial, dan minat yang berbeda tentang fasilitas apa yang menarik bagi mereka di taman. Taman ramah anak seharusnya dapat dinikmati oleh anak dari berbagai tahapan usia. Oleh karena itu, perlu ada penelitian lebih lanjut yang membahas mengenai sudut pandang pengguna secara spesifik di tiap kelompok umur yang berbeda terhadap prinsip-prinsip taman yang ramah anak.

\section{Referensi}

[1] UNICEF. Child Friendly Cities. 2009.

[2] Aziz NF, Said I. The Trends and Influential Factors of Children's Use of Outdoor 
Environments: A Review. Procedia - Soc Behav Sci 2012;38:204-12. https://doi.org/10.1016/j.sbspro.2012.03.341.

[3] Dewi SP. How Does The Playground Role in Realizing Children-Friendly-City? Procedia Soc Behav Sci 2012;38:224-33. https://doi.org/10.1016/j.sbspro.2012.03.344.

[4] Shi Y. Explore Children's Outdoor Play Spaces of Community Areas in High-density Cities in China: Wuhan as an Example. Procedia Eng 2017;198:654-82. https://doi.org/10.1016/j.proeng.2017.07.118.

[5] Kernan M. Outdoor Affordances in Early Childhood Education and Care Settings: Adults' and Children's Perspectives. Child Youth Environ 2010;20:152-77. https://doi.org/10.7721/chilyoutenvi.20.1.0152.

[6] Baskara M. Prinsip Pengendalian Perancangan Taman Bermain Anak Di Ruang Publik. J Lanskap Indones 2011;3:27-34. https://doi.org/10.29244/jli.2011.3.1.\%p.

[7] Samsudin, Artiningrum P. Evaluasi Kualitas Fisik dan Nonfisik pada Ruang Publik Terpadu Ramah Anak (RPTRA) (Studi Kasus: RPTRA Griya Tipar Cakung Jakarta Timur). Vitr J Arsitektur, Bangunan, Lingkung 2017;7:31-40.

[8] Rahmiati D, Prihastomo B. Identifikasi Penerapan Konsep Ruang Publik Terpadu Ramah Anak (RPTRA) Pada Taman Kambang Iwak Palembang. Vitr J Arsitektur, Bangunan, Lingkung 2018;8:29-42. https://doi.org/10.22441/vitruvian.2018.v8i1.004.

[9] Muhadjir N. Metodologi Penelitian Kualitatif. Yogyakarta: Rake Sarasin; 1996.

[10] Sukmadinata NS. Metode Penelitian Pendidikan. Bandung: Remaja Rosdakarya; 2011.

[11] Nour OEHM. Building Child Friendly Cities in the MENA region. Int Rev Educ 2013;59:489-504. https://doi.org/10.1007/s11159-013-9373-1.

[12] Said I. Architecture for children: Understanding Children Perception Towards Built Environment 2002.

[13] Horelli L. Creating child-friendly environments: Case studies on children's participation in three European countries. Childhood 1998;5:225-39. https://doi.org/10.1177/0907568298005002008.

[14] Hernowo E, Navastara AM. Karakteristik Ruang Publik Terpadu Ramah Anak (RPTRA) Bahari di Kecamatan Cilandak Jakarta Selatan. J Tek ITS 2017;6. https://doi.org/10.12962/j23373539.v6i2.25293.

[15] Thompson CW, Travlou P. Open Space: People Space. London: Taylor \& Francis; 2007. https://doi.org/10.4324/9780203961827.

[16] U.S. Consumer Product Safety Commision. Handbook for Public Playground Safety 2010.

[17] Worpole K. The Social Value of Public Spaces. York: Joseph Rowntree Foundation; 2007.

[18] Mariyana R, Nugraha A, Rachmawati Y. Pengelolaan Lingkungan Belajar. Jakarta: Kencana Prenada Media Group; 2013.

[19] Olsen H, Kennedy E, Vanos J. Shade Provision in Public Playgrounds for Thermal Safety and Sun Protection: A Case Study Across 100 Play Spaces in The United States. Landsc Urban Plan 2019;189:200-11. https://doi.org/10.1016/j.landurbplan.2019.04.003.

[20] Rousseau DM. Psychological Contracts in the Workplace: Understanding the Ties That Motivate. Acad Manag Exec 2004;18:120-7. https://doi.org/10.5465/ame.2004.12689213.

[21] Refshauge AD, Stigsdotter UK, Cosco NG. Adults' Motivation for Bringing Their Children 
to Park Playgrounds. Urban For Urban Green 2012;11:396-405. https://doi.org/10.1016/j.ufug.2012.06.002.

[22] Perry MA, Devan H, Fitzgerald H, Han K, Liu LT, Rouse J. Accessibility and Usability of Parks and Playgrounds. Disabil Health J 2018;11:221-9. https://doi.org/10.1016/j.dhjo.2017.08.011.

[23] Mustapa ND, Maliki NZ, Hamzah A. Repositioning Children's Developmental Needs in Space Planning: A Review of Connection to Nature. Procedia - Soc Behav Sci 2015;170:330-9. https://doi.org/10.1016/j.sbspro.2015.01.043.

[24] Matthews MH. Making Sense of Place: Children's Understanding of Large-Scale Environments. Harvester Wheatsheaf; 1992.

[25] Muthmainnah, Astuti B, Fatimaningrum AS. Pengembangan Panduan Permainan Untuk Engoptimalkan Perkembangan Sosial Emosional Anak Usia Dini. J Pendidik Anak 2016;5. https://doi.org/10.21831/jpa.v5i1.12363. 